\title{
MARITIME SECURITY COOPERATION WITHIN THE ASEAN INSTITUTIONAL FRAMEWORK: A GRADUAL SHIFT TOWARDS PRACTICAL COOPERATION
}

\author{
I Gusti Bagus Dharma Agastia \\ International Relations Study Programme, Faculty of Humanities, President University \\ Jalan Ki Hajar Dewantara, Jababeka, Cikarang Baru, Jawa Barat 17550 \\ agastia@president.ac.id
}

Received: $07^{\text {th }}$ January 2021/ Revised: $31^{\text {st }}$ March 2021/ Accepted: $19^{\text {th }}$ April 2021

How to Cite: Agastia, I. G. B. D. (2021). Maritime security cooperation within the ASEAN institutional framework: A gradual shift towards practical cooperation. Journal of ASEAN Studies, 9(1), 25-48, https://doi.org/10.21512/jas.v9i1.6919

\begin{abstract}
How does ASEAN fare in addressing maritime security problems? This paper examines the shifting character of maritime security cooperation in Southeast Asia. In doing so, this paper looks at the outcomes of three maritime security-oriented for that exist within the ASEAN regional framework: the ASEAN Regional Forum, the ASEAN Defence Ministers' Meeting, and the ASEAN Maritime Forum. By compiling and analysing data on the forms and frequency of existing cooperative activities from 2003 gathered from publicly available sources, this paper finds that maritime security cooperation among ASEAN members continue to be largely dialogue-based, with few instances of practical cooperation. By comparing the three fora, this paper argues that the organisational design of these forums tends to affect the forms of cooperation. This paper concludes that despite ASEAN showing progress in adopting practical security cooperation, there remain hurdles in achieving regional maritime security.
\end{abstract}

Keywords: ASEAN, maritime security, regional institutions, security cooperation

\section{INTRODUCTION}

Since 2003, ASEAN has decided to prioritise maritime security as a regional problem. As a result, there have been numerous efforts to promote regional solutions to regional maritime security problems through ASEAN's multilateral bodies. In the ASEAN Regional Forum (ARF), the security cooperation agenda has largely centred on disaster relief, counterterrorism, and maritime security. In maritime security, Haacke (2009, p. 446) found that 1) dialogue among ARF members have resulted in 'basic agreement on a normative 
framework' which serves to guide future cooperation, and 2) capacity-building exercises, which constitute the bulk of practical security cooperation, are often conducted outside the auspices of the ARF. This paper seeks to expand on Haacke's initial findings to see whether the observed turn towards practical cooperation has been sustained. To that end, this paper examines the outcomes and efforts of maritime security-oriented fora, such as the ARF Intersessional Meeting on Maritime Security, the ASEAN Defence Ministers' Meeting (ADMM) and ADMM-Plus, and the ASEAN Maritime Forum. These fora are considered important interlocutors of maritime security cooperation in the ASEAN region, as they have allowed member states to organise meetings, workshops, and operational exercises. However, these three fora are not alike; their design and purposes play a role in either expediting or inhibiting more 'practical' cooperation activities.

This paper proceeds in four main sections. The first section reviews the literature on security cooperation in Southeast Asia. The second section describes the analytical framework, along with the methodology of this paper. In the third section, this paper reviews the multilateral processes related to maritime security cooperation in ASEAN. Three major regional platforms for maritime security cooperation are reviewed: the ASEAN Regional Forum, specifically the Intersessional Meeting on Maritime Security (ARF ISM on MS), the ASEAN Defence Ministers Meeting (ADMM) and the ADMM Plus, and the ASEAN Maritime Forum (AMF) along with the Expanded ASEAN Maritime Forum (EAMF), along with their key outcomes of the platforms. The fourth section provides a discussion of the results of the third section, particularly on the relation between organisational design and character of security cooperation.

\section{LITERATURE REVIEW}

\section{The maritime security discourse in ASEAN}

Within ASEAN, there were already discussions of regional maritime security cooperation in the late 1990s. The 1998 Hanoi Declaration and subsequent Plan of Action to Combat Transnational Crime in 1999 showed a regional focus on piracy and armed robbery. These declarations were issued as a response to an uptick in piracy and armed robbery after the Asian Financial Crisis in 1997. The Hanoi Declaration noted piracy as a specific object of concern for ASEAN members, though it only mentioned the need to 'intensify individual and collective efforts' to address piracy and other transnational crimes. The subsequent Plan of Action conveyed ASEAN's interests in institutionalising responses to transnational crime by establishing the ASEAN Centre for Combating Transnational Crime (ACTC) and positioning the ASEAN Ministerial Meeting on Transnational Crime as the highest policymaking unit. This response, however, was mostly limited to transnational crime, and while piracy does fall within this category, the Plan of Action does not provide specific guidelines on a regional response to piracy. In this vein, maritime security was still viewed in the narrow sense of transnational crime, which was to be addressed individually by member states. A more specific call to action was issued by the ARF in June 2003. The joint statement noted the 'indispensable and fundamental' nature of maritime security and the urgency to 'step up broad-based regional cooperative efforts' between the relevant maritime law enforcement institutions. The statement 
also urged the implementation and adoption of international instruments and guidelines, such as the 1988 SUA Convention and the 1974 International Convention for the Safety of Life at Sea (Nasu et al., 2019).

In addition to intramural efforts to come together on maritime security cooperation, there were also extra-regional efforts at maritime security, most notably from Japan and the United States (U.S.). In response to the 9/11 attacks, the U.S. issued three distinct security initiatives: the Container Security Initiative, Proliferation Security Initiative, and Regional Maritime Security Initiative (RMSI). While the first two initiatives were implemented globally, RMSI was exclusively focused on securing the Malacca Strait from the threat of terrorism. Through RMSI, the U.S. sought to deepen cooperative ties with littoral states, namely Singapore, Indonesia, and Malaysia, in maritime security efforts in the Malacca Strait. In his testimony to the House Armed Services Committee on 31 March 2004, Admiral Thomas Fargo of the United States Navy noted RMSI would include working together with regional navies to 'build and synchronize interagency and international capacity to fight threats that use maritime space to facilitate their illicit activity.' (House Armed Services Committee, 2004) Fargo's subsequent statement explaining how cooperation under RMSI would be operationalized'...we are looking at things like high-speed vessels, putting Special Operations Forces on highspeed vessels, putting potentially Marines on high-speed vessels so that we can use boats that might be incorporated with these vessels to conduct effective interdiction'—generated staunch opposition from both Malaysia and Indonesia due to concerns of U.S. military presence in the Malacca Strait (Febrica, 2015, p. 123; Rosenberg \& Chung, 2008). In contrast, Japan, seeking to secure the flow of trade in the Malacca Strait, proposed the Regional Agreement on Cooperation Against Armed Piracy (ReCAAP) in 1999, which entered into force in 2006. The ReCAAP initiative would be led by Japan and involved increasing coast guard cooperation and the establishment of a regional information-sharing centre to monitor and counter piracy and armed robbery. These attempts, however, saw mixed reception among ASEAN members. Indonesia and Malaysia were among the strongest opponents of the initiatives, citing sovereignty concerns (Storey, 2009, p. 40).

Several institutional changes in the early 2000s drove maritime security to the forefront of ASEAN. Chief among them was the second Declaration of ASEAN Concord (also known as the Bali Concord II), issued in October 2003 (Nasu et al., 2019, p. 117). It established maritime security as an organisational goal and specifically acknowledged the need for a regional response based on 'common values' in addressing maritime security threats. It noted the transboundary nature of maritime issues, which warrants a 'holistic, integrated, and comprehensive' response from ASEAN members, which would take the form of an ASEAN Security Community. In the Vientiane Action Programme (specifically Part II, sec. 1.3.), maritime security cooperation was to be further promoted as a means to prevent conflict, which would be facilitated by the creation of an ASEAN maritime forum. The idea of a maritime forum was also carried over into the ASEAN Political Security Community (APSC) Blueprint 2015. In promoting maritime security cooperation, the Blueprint endorses the establishment of the ASEAN Maritime Forum, application of a 'comprehensive approach' on safety of navigation and security concerns that are 'of common concerns to the ASEAN Community', 
stocktaking and identifying maritime issues and cooperation among ASEAN members, and promoting cooperation in maritime search-and-rescue activities (ASEAN, 2009, sec. A.2.5).

As a result of this regional emphasis on maritime security, maritime security cooperation activities began to become part of ASEAN's security agenda. However, while it was expected that the character of security cooperation would be a balanced blend of 'traditional' and 'non-traditional' security cooperation, in reality, maritime security cooperation has mostly been 'non-traditional' in nature. While 'traditional' engagements persist at the bilateral level, there is a general aversion at the regional level to these forms of engagement (Bhattacharyya, 2010). Part of this aversion is attributed to ASEAN's reluctance to be branded as a military bloc; another reason is the need for consensus, which incentivises members to focus on the lowest common denominator. As such, maritime security cooperation in Southeast Asia has mostly revolved around counterpiracy, maritime terrorism, and countering illegal fishing (Damayanti, 2018).

\section{On the effectiveness of Southeast Asian maritime security cooperation}

In discussing security cooperation, observers often argue about the proper way of gauging the general effectiveness of regional institutions, and, in turn, the effectiveness of maritime security cooperation. While this paper does not seek to test nor examine the effectiveness of maritime security cooperation activities or that of ASEAN's regional institutions, the indicators of effectiveness do merit a brief review. In the literature of ASEAN, this debate is particularly noticeable, especially in assessing institutional outcomes, leading to assessments of the perceived value of regional institutions (Stubbs, 2019). These views stem from differing fundamental understandings of how power is wielded by regional institutions (Eaton \& Stubbs, 2006). On the one hand, ASEAN sceptics tend to point out at the lack of practical outcomes produced by ASEAN bodies. This is often attributed to the consensusseeking, informal, and intergovernmental character of ASEAN institutions which are enshrined in the values of the so-called 'ASEAN Way' (D. M. Jones \& Smith, 2007; L. Jones, 2010). Viewed in this light, ASEAN processes arguably have less power in both encouraging and discouraging conduct. On the other hand, ASEAN proponents tend to view the development and exercise of existing regional processes as an indicator of ASEAN's performance as a regional institution (Acharya, 2009a, 2009b; Katsumata, 2006; Yates, 2017). Proponents argue that ASEAN's success and value as a regional institution should not be assessed in strictly practical terms as the sceptics suggest; rather, it ought to be assessed in ASEAN's progress in disseminating and shaping common values through constructive regional processes. In other words, the process matters more than outcomes.

In assessing the outcomes of ASEAN maritime security cooperation, it would seem there is a preference for outcomes instead of processes in the literature. Bradford (2005, p. 64), for example, proposes a simple method for determining whether specific maritime security cooperation activities are effective. Cooperation is considered effective when it is 'operationalised', i.e., a 'specific type and degree of cooperation in which policies addressing common threats can be carried out by midlevel officials of the states involved without 
immediate or direct supervision from strategic-level authorities.' This is contrasted with just 'cooperation', e.g., high-level consultations or information sharing agreements, which usually reflect political commitments, but not actual practices in the field. Haacke (2009) adopts a similar approach, which will be discussed further in the following section. This tendency towards practical cooperation being the yardstick for organisational progress in security cooperation is also reflected in academic literature of Southeast Asian security cooperation (see, among others, Tan, 2016, 2020).

\section{Analytical framework}

Haacke (2009) categorised cooperation into two broad forms: 'dialogue' and 'practical' cooperation. 'Dialogue' refers to forms of security cooperation centred on the routine sharing of experiences, often with the goal of confidence-building. In some circumstances, 'dialogue' forms of security cooperation often generate outcomes in the form of statements, ranging from affirmation of pre-existing commonly agreed principles, pledges or plans for further cooperation, to definitive joint statements. Among the three institutions, 'dialogue'-based security cooperation generally take the form of routine meetings or workshops. 'Practical' cooperation explicitly refers to tangible results in information-sharing initiatives, field exercises, tabletop exercise, or related capacity-building exercises. Workshops which do not incorporate field activities are instead categorised as 'dialogue' activities. Second, a temporal dimension to the previous categorisation is added. This allows further distinction between routine activities, such as annual meetings or periodical workshops, and incidental activities, such as a one-off joint naval exercise or a thematic workshop.

\begin{tabular}{|c|c|c|}
\hline & Dialogue & Practical \\
\hline Incidental & $\begin{array}{l}\text { A form of dialogue that only occurs } \\
\text { once. This category also covers special } \\
\text { events, such as the Bali Concord. (D-I) }\end{array}$ & $\begin{array}{l}\text { Practical security cooperation that only } \\
\text { occurs once, with low prospect of } \\
\text { recurrence, such as a one-off instance of } \\
\text { a naval exercise. (P-I) }\end{array}$ \\
\hline Sustained & $\begin{array}{l}\text { A form of dialogue that occurs on a } \\
\text { routine and sustained basis. This } \\
\text { category covers the routine meetings } \\
\text { conducted within the forums. (D-S) }\end{array}$ & $\begin{array}{l}\text { Practical security cooperation that is } \\
\text { routine and sustained or has occurred } \\
\text { once with high prospects of recurrence. } \\
(\mathrm{P}-\mathrm{S})\end{array}$ \\
\hline
\end{tabular}

Figure 1 Categorisation of Cooperative Activities, Modified from Haacke, 2009.

The distinction between 'dialogue' and 'practical' is not mutually exclusive. In some cases, practical security cooperation first requires robust dialogue processes. These are usually required to coordinate logistical needs and the intended objectives of the exercise. Second, some workshops, which ought to fall under the 'dialogue' category, do involve a form of 'practical' activity, such as table-top exercises. The cooperative activity will be classified as 'practical' in the case where table-top exercises constitute the bulk of the activity. 


\section{METHODOLOGY}

In gathering the data on instances of maritime security cooperation, this paper refers to official data on maritime security cooperative activities from relevant ASEAN sources, such as the ASEAN website, ARF ISM-MS Co-Chair Reports, the ADMM website, and other official sources related to ASEAN bodies. Official data is then cross-referenced with relevant press releases or publicly available news to further identify the nature of the cooperative activity. Once identified, the cooperative activity is then subjected to categorization based on Figure 1. The frequency of cooperative activities is then presented in a simple clustered bar graph. Additional details of activities are provided in tables.

\section{DISCUSSION AND ANALYSIS}

\section{The ASEAN Regional Forum (ARF)}

The ARF was one of the forerunners in institutionalising maritime security cooperation in Southeast Asia. In August 2004, following their statement on maritime security, the ARF conducted a roundtable discussion on the stocktaking of maritime issues. The roundtable was an attempt to generate a common understanding of maritime security among ARF members. Participants of the roundtable agreed on a common set of principles of maritime security, which include adherence to UNCLOS 1982, a respect for the 'ASEAN Way' and the ARF principles of preventive diplomacy, and the facilitation of information-sharing efforts. The roundtable also noted six lessons for maritime security cooperation, derived from the experience of the participants:1) the need for interagency technical cooperation, 2) information sharing, 3) learning of each other's cultures, 4) the need to complement efforts instead of competing, 5) the need to implement plans, policies, and operational activities, and 6) the need for integrating training and exercise plans, Standard Operating Procedures, education, and legal cooperation (ARF, 2007). The most notable outcome of the roundtable, however, was an agreement on common maritime security concerns, which among others, included a need for increased exchanges in information-sharing capabilities and capacity-building measures. It would, however, take five more years before the ARF had a platform dedicated to discussing maritime security. The Intersessional Meeting on Maritime Security (ISM on MS) was formally agreed upon in the $15^{\text {th }}$ ARF Ministerial Meeting in 2008.

In March 2009, the first ARF Intersessional Meeting on Maritime Security (ISM on MS) was held. The Meeting is designed to facilitate dialogue among members and hopefully motivate members to initiate maritime security related programs. In other words, it is intended to turn dialogue into practical cooperation (Haacke, 2009). The themes, or Priority Areas, discussed in the ISM on MS are outlined in the Maritime Security Work Plan, which is updated every three years. In the most recent 2018-2020 Work Plan, the Priority Areas covered include: shared awareness and exchange of information and best practices, confidence-building measures based on international and regional legal frameworks, and capacity building and enhancing maritime law enforcement agencies (ARF, 2018). Several notable discussions that have occurred in the ISM on MS include finding common ground on legal interpretations; 
informational exchange and interagency cooperation; safety at sea; and coordination between regional maritime law enforcement agencies and existing maritime security initiatives (see Table 1).

Table 1. Selected discussions in ISM on MS, 2009-2019 based on Co-Chair Summary Reports.

\begin{tabular}{|c|c|}
\hline Priority areas & Examples \\
\hline $\begin{array}{l}\text { Common ground on } \\
\text { interpretation of legal regimes }\end{array}$ & $\begin{array}{l}\text { Discussions on the principle of freedom of navigation in the EEZ } \\
\text { ( } 1^{\text {st }} \text { Meeting, 2009). } \\
\text { Development of a cooperative regional system to enforce } \\
\text { implementation of international conventions such as COLREGS and } \\
\text { SOLAS, along with bilateral recognition of rules and a standard of } \\
\text { behaviour at sea }\left(7^{\text {th }} \text { Meeting, 2015). }\right.\end{array}$ \\
\hline Information sharing schemes & $\begin{array}{l}\text { - Possibility for mechanisms and procedures for sharing classified } \\
\text { information on potential maritime security threats }\left(4^{\text {th }} \text { Meeting, }\right. \\
2012) \\
\text { The use of information sharing centres to provide vital information } \\
\text { on illegal activities at sea }\left(10^{\text {th }} \text { Meeting, 2018). }\right.\end{array}$ \\
\hline Confidence building measures & $\begin{array}{l}\text { - Continuation of confidence building measures in enhancing } \\
\text { maritime domain awareness }\left(10^{\text {th }} \text { Meeting, 2018) }\right.\end{array}$ \\
\hline $\begin{array}{l}\text { Capacity-building and technical } \\
\text { cooperation }\end{array}$ & $\begin{array}{l}\text { Prospects of operationalising a regional coast guard }\left(4^{\text {th }} \text { Meeting, }\right. \\
\text { 2012). } \\
\text { Increasing capacity to effectively combat IUU fishing }\left(10^{\text {th }} \text { Meeting, }\right. \\
\text { 2018). }\end{array}$ \\
\hline
\end{tabular}

\section{Key outcomes of the ISM on MS}

The ISM on MS has produced three Work Plans on Maritime Security, which provide a common point of reference for maritime security issues deemed important to the member states. In general, the Work Plans encourage members states to propose relevant projects, such as capacity-building workshops, table-top or field exercises, training, and studies on selected aspects of maritime security related to the Priority Areas defined by the Work Plan. Since the first Work Plan in 2011, these Priority Areas have remained consistent.

The activities of the ISM on MS are largely dialogue-based, though several workshops may provide skills training. Meetings are centred on general discussions and updates of the Work Plan, whereas workshops prioritise sharing of information and experience. Practical cooperation tends to be rare (see Table 2 and Chart 1). The only ARF-sponsored event involving practical cooperation was the Maritime Shore Exercise. In the 2006 Concept Paper, proposed by Singapore, the exercise would be an 'important step forward following the successful dialogues on maritime security' (ARF, 2006). The Exercise, conducted on 22-23 January 2007, included professional exchanges between maritime security agencies of the participants, both simulation and table-top exercises, and a tactical trainer exercise (MINDEF, 2007). Another workshop was conducted in 2019, but the scale was less ambitious compared 
to the 2007 Shore Exercise. The exercise, dubbed the 'ARF Workshop and Tabletop Exercise on Crimes related to Fisheries', was proposed by Indonesia with the U.S. as a co-chair. The aim was to 'develop a common understanding of the serious nature and extent of criminal offences' in the fisheries sector. Like other workshops considered and endorsed by the ISM on MS, the workshop aimed to facilitate experience and expertise sharing and capacity building (ARF, 2019). There is also a tendency for initially thematic dialogue-based activities to be continued in the later years, such as the workshop on ferry safety and on UNCLOS, which may hint towards more specialised practical cooperation between member states.

Table 2 List of Track 1 activities related to maritime security. Full dataset (until 2019) available online at http://aseanregionalforum.asean.org/wp-content/uploads/2020/03/List-ofARF-Track-I-Activities-by-Inter-Sessional-Year-as-of-10-Dec-2019.pdf. Activities in 2020 from http://aseanregionalforum.asean.org/calendar-of-events/schedule-of-arf-meetings-andactivities/

\begin{tabular}{|c|c|}
\hline Name of event/activity & Date and location held \\
\hline Meeting of Specialist Officials on Maritime Issues & Honolulu, 5 November 1998 \\
\hline ARF Workshop on Maritime Security Challenges & Mumbai, 27 Feb - 1 March 2003 \\
\hline ARF Workshop on Maritime Security & Kuala Lumpur, 22-24 September 2004 \\
\hline ARF CBM on Regional Cooperation in Maritime Security & Singapore, 2-4 March 2005 \\
\hline Workshop on Training for the Cooperative Maritime Security & Kochi, India 26-28 October 2005 \\
\hline Workshop on Capacity Building of Maritime Security & Tokyo, 19-20 December 2005 \\
\hline Maritime Security Shore Exercise Planning Conference & Singapore, 7-8 December 2006 \\
\hline Maritime Security Shore Exercise & Singapore, 22-23 January 2007 \\
\hline ARF Roundtable Discussion on Stocktaking of Maritime Security Issues & Bali, 24-25 August 2007 \\
\hline ARF Maritime Security Training Programme & Chennai, 24-29 March 2008 \\
\hline Second (Advanced) Maritime Security Training Programme for ARF Member & Chennai, 17-22 November 2008 \\
\hline \multicolumn{2}{|l|}{ States } \\
\hline $1^{\text {st }}$ ARF Intersessional Meeting on Maritime Security (ISM on MS) & Surabaya, 5-6 March 2009 \\
\hline ARF Seminar on Measures to Enhance Maritime Security & Brussels, 19-20 November 2009 \\
\hline $2^{\text {nd }} \mathrm{ARF}$ ISM on MS & Auckland, 29-30 March 2010 \\
\hline $3^{\text {rd }}$ ARF ISM on MS & Tokyo, 14-15 February 2011 \\
\hline ARF Seminar on UN Convention on the Law of the Sea (UNCLOS) & Manila, 8-9 March 2011 \\
\hline $4^{\text {th }}$ ARF ISM on MS & San Francisco, 14-15 June 2012 \\
\hline ARF Workshop on Shop Profiling & Kuala Lumpur, 14-15 April 2013 \\
\hline $5^{\text {th }}$ ARF ISM on MS & Seoul, 18-19 April 2013 \\
\hline ARF Maritime Security Workshop on Marine Environmental Protection & Honolulu, 4-5 March 2014 \\
\hline \multicolumn{2}{|l|}{ Cooperation: Preparedness and Response to Pollution Incidents involving } \\
\hline \multicolumn{2}{|l|}{ Hazardous and Noxious Substances } \\
\hline $6^{\text {th }}$ ARF ISM on MS & Bali, 22-23 May 2014 \\
\hline $2^{\text {nd }}$ ARF Seminar on UNCLOS & Manila, 28-29 May 2014 \\
\hline $7^{\text {th }}$ ARF ISM on MS & Honolulu, 30 March - 1 April 2015 \\
\hline ARF Workshop on Maritime Risks Management and Cooperation & Beijing, 13-15 December 2015 \\
\hline ARF Workshop on Marine Oil Spill Emergency Response Management and & Kunming, 17-18 December 2015 \\
\hline \multicolumn{2}{|l|}{ Disposal Cooperation } \\
\hline $8^{\text {th }}$ ARF ISM on MS & Manila, 6-7 April 2016 \\
\hline ARF Workshop on Illegal, Unreported, and Unregulated Fishing & Bali, 20-21 April 2016 \\
\hline ARF Workshop on National Maritime Single Point of Contact & Cebu, 28-29 April 2016 \\
\hline ARF Capacity Building Workshop on Ship Profiling & Kuala Lumpur, 24-25 May 2016 \\
\hline ARF Workshop on Management of Marine Hazards in the Asia-Pacific & Beijing, 6-8 December 2016 \\
\hline $9^{\text {th }}$ ARF ISM on MS & Tokyo, 8-9 February 2017 \\
\hline
\end{tabular}


Table 2 List of Track 1 activities related to maritime security. Full dataset (until 2019) available online at http://aseanregionalforum.asean.org/wp-content/uploads/2020/03/List-ofARF-Track-I-Activities-by-Inter-Sessional-Year-as-of-10-Dec-2019.pdf. Activities in 2020 from http://aseanregionalforum.asean.org/calendar-of-events/schedule-of-arf-meetings-andactivities/

(Continued)

\begin{tabular}{|c|c|}
\hline Name of event/activity & Date and location held \\
\hline ARF Workshop on Ferry Safety & Guangzhou, 12-13 December 2017 \\
\hline $\begin{array}{l}1^{\text {st }} \text { ARF Workshop on Enhancing Regional Maritime Law Enforcement } \\
\text { Cooperation }\end{array}$ & Nha Trang, 18-19 January 2018 \\
\hline ARF Workshop on International Cooperation on Maritime Domain Awareness & Tokyo, 7-8 March 2018 \\
\hline $10^{\text {th }}$ ARF ISM on MS & Brisbane, 27-28 March 2018 \\
\hline $\begin{array}{l}\text { ARF Workshop on Best Practices in Using Maritime Data to Combat } \\
\text { Transnational Organized Crime }\end{array}$ & Bali, 17-19 July 2018 \\
\hline $2^{\text {nd }}$ ARF Workshop on Ferry Safety & Guangzhou, 26-28 November 2018 \\
\hline $\begin{array}{l}1^{\text {st }} \text { ARF Workshop on Implementing UNCLOS and other International } \\
\text { Instruments to Address Emerging Maritime Issues }\end{array}$ & Nha Trang, 26-27 February 2019 \\
\hline $11^{\text {th }}$ ARF ISM on MS & Da Nang, 14-15 March 2019 \\
\hline $\begin{array}{l}2^{\text {nd }} \text { ARF Workshop on Enhancing Regional Maritime Law Enforcement } \\
\text { Cooperation }\end{array}$ & Da Nang, 25-26 March 2019 \\
\hline $\begin{array}{l}\text { ARF Workshop and Table-Top Exercise on Enhancing Law Enforcement, } \\
\text { Preventive Measures and Cooperation to Address Complex Issues in the } \\
\text { Fisheries Sector }\end{array}$ & Bali, 26-28 June 2019 \\
\hline $\begin{array}{l}2^{\text {nd }} \text { ARF Workshop on Implementing UNCLOS and other International } \\
\text { Instruments to Address Emerging Maritime Issues }\end{array}$ & Hanoi, 13-14 November 2019 \\
\hline $3^{\text {rd }}$ ARF Workshop on Ferry Safety & Guangzhou, 12-13 November 2019 \\
\hline $\begin{array}{l}2^{\text {nd }} \text { ARF Workshop on International Cooperation on Maritime Domain } \\
\text { Awareness }\end{array}$ & Tokyo, 20 February 2020 \\
\hline ARF Workshop on Dispute Resolution and the Law of the Sea & Dili, 27-28 February 2020 \\
\hline $12^{\text {th }}$ ARF ISM on MS & $\begin{array}{l}\text { Spain, to be conducted in intersessional } \\
\text { year } 2019-2020\end{array}$ \\
\hline $\begin{array}{l}3^{\text {rd }} \text { ARF Workshop on Enhancing Regional Maritime Law Enforcement } \\
\text { Cooperation }\end{array}$ & $\begin{array}{l}\text { Spain, to be conducted in intersessional } \\
\text { year 2019-2020 }\end{array}$ \\
\hline $\begin{array}{l}\text { ARF Workshop on Maritime Law Enforcement Promoting Comprehensive } \\
\text { Approach to Address Maritime Crimes }\end{array}$ & $\begin{array}{l}\text { Kuala Lumpur, to be conducted in } \\
\text { intersessional year 2019-2020 }\end{array}$ \\
\hline $\begin{array}{l}\text { International Ship and Port Facility Security Code Training Series and Manual } \\
\text { Part } 1\end{array}$ & $\begin{array}{l}\text { Papua New Guinea, to be conducted in } \\
\text { intersessional year 2019-2020 }\end{array}$ \\
\hline $\begin{array}{l}\text { International Ship and Port Facility Security Code Training Series and Manual } \\
\text { Part } 2\end{array}$ & $\begin{array}{l}\text { Mumbai, to be conducted in } \\
\text { intersessional year 2019-2020 }\end{array}$ \\
\hline $\begin{array}{l}\text { International Ship and Port Facility Security Code Training Series and Manual } \\
\text { Part } 3\end{array}$ & $\begin{array}{l}\text { Manila, to be conducted in } \\
\text { intersessional year 2019-2020 }\end{array}$ \\
\hline
\end{tabular}




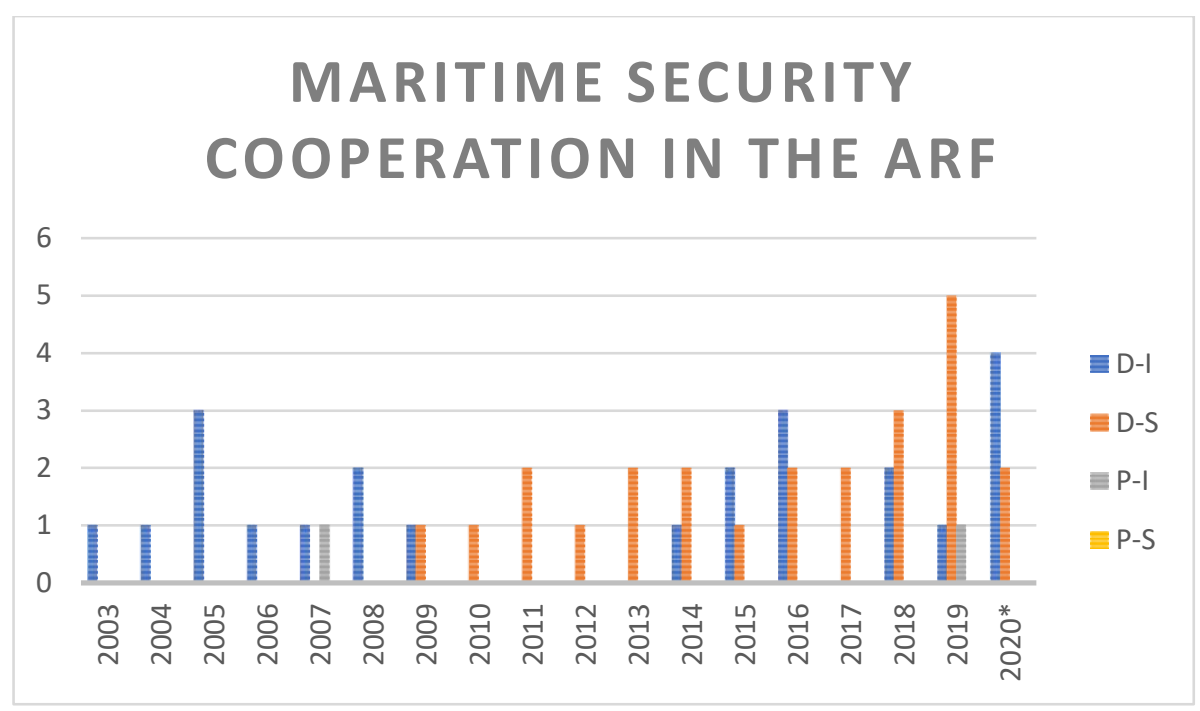

Chart 1. Frequency of maritime security cooperation activities in the ARF, 2003-2020.

$\left(^{*}\right)$ indicates a year where data for activities that have yet to be conducted despite being planned for the specified year, and as such, the character of those activities cannot be precisely determined.

\section{The ASEAN Defence Ministers Meeting (ADMM)}

The ADMM was established in 2006 as the highest meeting of defence officials in ASEAN. Prior to the ADMM, the ARF was the preferred venue for ASEAN defence officials to convene, albeit informally, under the ARF Defence Officers Dialogue and ARF Security Policy Conference. Outside of the ARF, ASEAN already had numerous venues for defence officials to interact. The ASEAN Special Senior Officials' Meeting (SOM) had provided a venue for the meeting of defence officials since 1996, and military-to-military interactions, including intra-ASEAN military exercises, which had already been conducted since as early as 1972, in addition to specialised fora, such as the ASEAN Navy Interaction and the ASEAN Chiefs of Defence Informal Meeting (Chalermpalanupap, 2011; Tan, 2016).

Given these modalities, the ADMM seemed like a logical next step for ASEAN multilateral security cooperation. There were concerns that the ARF would not be wellequipped to address rising challenges, particularly the emergence of China. ASEAN members particularly recognised the inherent limitations of the ARF's institutional design; its diverse membership meant that much time had to be spent on confidence-building and addressing diverging perceptions on the idea of 'preventive diplomacy', which leaves less time for exploring practical security cooperation (Tang, 2016; Yuzawa, 2006). At the same time, discussions of advancing the vision of an ASEAN Security Community, initiated by the Bali Concord II and further elaborated in the Vientiane Action Programme, provided a push for developing intramural security cooperation. This was also in light of mounting security challenges faced by the region, such as terrorism and maritime piracy (Ba, 2017).

The ADMM-Plus would later be established to include ASEAN Dialogue Partners. The goal of the ADMM and ADMM-Plus is similar to that of the ARF; namely, to promote 
cooperation and dialogue on both traditional and non-traditional security issues in Southeast Asia. However, the ADMM and ADMM-Plus are more equipped for implementing practical cooperation on top of their dialogue function. This is achieved through three methods. First, the agenda is set by defence ministers and officials instead of foreign ministers. Second, the ADMM-Plus makes extensive use of Expert Working Groups (EWGs), which allows for a 'focused, task-oriented approach to security cooperation' that involves technicians rather than diplomats. Third, ADMM-Plus membership is much more selective. In addition to the ten ASEAN member states, the ADMM-Plus only admits eight external Dialogue Partners. The smaller membership pool helps reduce friction in deciding and implementing programs $(\mathrm{Ba}$, 2017, pp. 150-152).

At the core of the ADMM-Plus are the EWGs, which are specialised sub-units that work to provide and proposals to the ADMM. There are several EWGs, each dealing with a specific area in a similar fashion to the ARF Intersessional Meetings. Table 3 lists the relevant activities of the EWG on Maritime Security.

Table 3. List of Track 1 activities by the ADMM and ADMM-Plus related to maritime security, up until 2019. Available online: https://admm.asean.org/index.php/events/pastmeetings-and-events.html. Data for 2020 is unavailable as the EWG on MS has no scheduled meetings or activities.

\begin{tabular}{|c|c|}
\hline Name of event/activity & Date and location held \\
\hline $1^{\text {st }}$ ADMM-Plus EWG on Maritime Security & Australia, 19-20 July 2011 \\
\hline $2^{\text {nd }}$ ADMM-Plus EWG on Maritime Security & Malaysia, 8-10 February 2012 \\
\hline $3^{\text {rd }}$ ADMM-Plus EWG on Maritime Security and Tabletop Exercise (TTX) & Japan, 17-20 July 2012 \\
\hline $4^{\text {th }}$ ADMM-Plus EWG on Maritime Security & Australia, 26-28 November 2012 \\
\hline $\begin{array}{l}5^{\text {th }} \text { ADMM-Plus EWG on Maritime Security and Mid-Planning Conference } \\
\text { for the ADMM-Plus Maritime Security Field Training Exercise (FTX) }\end{array}$ & Penang, 27-30 May 2013 \\
\hline Final Planning Conference for the ADMM-Plus Maritime Security FTX & Sydney, 27 June 2013 \\
\hline Final Site Survey for the ADMM-Plus Maritime Security FTX & Indonesia, 13-15 August 2013 \\
\hline $6^{\text {th }}$ ADMM-Plus EWG on Maritime Security & Sydney, 30 September - 1 October 2013 \\
\hline $7^{\text {th }}$ ADMM-Plus EWG on Maritime Security and Maritime Security Seminar & Melaka, 23-24 January 2014 \\
\hline $\begin{array}{l}8^{\text {th }} \text { ADMM-Plus EWG on Maritime Security and Workshop on Counter- } \\
\text { piracy operations }\end{array}$ & Auckland, 23-26 June 2014 \\
\hline $9^{\text {th }}$ ADMM-Plus EWG on Maritime Security and TTX & Brunei Darussalam, 27-31 October 2014 \\
\hline $\begin{array}{l}\text { Initial Planning Conference of ADMM-Plus Maritime Security and } \\
\text { Counterterrorism Exercise }\end{array}$ & Brunei Darussalam, 2-6 February 2015 \\
\hline ADMM-Plus EWG on Maritime Security Future Leaders' Programme & Auckland, 13-17 September 2015 \\
\hline $10^{\text {th }}$ ADMM-Plus EWG on Maritime Security & Auckland, 15-16 September 2015 \\
\hline $\begin{array}{l}\text { Middle Planning Conference of ADMM-Plus Maritime Security and } \\
\text { Counterterrorism Exercise }\end{array}$ & Singapore, 19-22 October 2015 \\
\hline $\begin{array}{l}\text { Initial Planning Conference for the ADMM-Plus Field Training Exercise on } \\
\text { Maritime Security "Exercise Mahi Tangaroa" }\end{array}$ & Brunei Darussalam ,27-28 January 2016 \\
\hline $\begin{array}{l}\text { Final Planning Conference for the ADMM-Plus Maritime Security and } \\
\text { Counter-Terrorism Exercise }\end{array}$ & Singapore, 1-3 March 2016 \\
\hline ADMM-Plus Maritime Security and Counter-Terrorism Exercise & $\begin{array}{l}\text { Brunei Darussalam and Singapore, 2-12 } \\
\text { May } 2016\end{array}$ \\
\hline $\begin{array}{l}\text { Final Planning Conference for the ADMM-Plus Field Training Exercise on } \\
\text { Maritime Security "Exercise Mahi Tangaroa" }\end{array}$ & Auckland, 23-26 May 2016 \\
\hline
\end{tabular}


Table 3. List of Track 1 activities by the ADMM and ADMM-Plus related to maritime security, up until 2019. Available online: https://admm.asean.org/index.php/events/pastmeetings-and-events.html. Data for 2020 is unavailable as the EWG on MS has no scheduled meetings or activities.

(Continued)

\begin{tabular}{|c|c|}
\hline Name of event/activity & Date and location held \\
\hline $11^{\text {th }}$ ADMM-Plus EWG on Maritime Security & Auckland, 13-16 November 2016 \\
\hline $\begin{array}{l}\text { ADMM-Plus Field Training Exercise on Maritime Security "Exercise Mahi } \\
\text { Tangaroa" }\end{array}$ & Auckland, 13-16 November 2016 \\
\hline $12^{\text {th }}$ ADMM-Plus EWG on Maritime Security & 1-3 November 2017 \\
\hline $\begin{array}{l}\text { Ad Hoc Working Group Meeting and Initial Planning Conference on the } \\
\text { ASEAN-China Maritime Exercise }\end{array}$ & Singapore, 25-27 April 2018 \\
\hline $13^{\text {th }}$ ADMM-Plus EWG on Maritime Security & Seoul, 30 May - 1 June 2018 \\
\hline $\begin{array}{l}\text { ADMM-Plus Experts' Working Group on Maritime Security Future Leaders' } \\
\text { Programme }\end{array}$ & Singapore, 17-21 June 2018 \\
\hline ASEAN-China Maritime Exercise Middle Planning Conference & Zhanjiang, China, 3-6 July 2018 \\
\hline $\begin{array}{l}\text { ASEAN-China Maritime Exercise Final Planning Conference and Table-Top } \\
\text { Exercise }\end{array}$ & Singapore, 1-3 August 2018 \\
\hline ASEAN-China Maritime Exercise Field Training Exercise & Zhanjiang, China, 20-28 October 2018 \\
\hline $\begin{array}{l}\text { ADMM-Plus Experts' Working Group on Maritime Security Table-Top } \\
\text { Exercise and Middle Planning Conference }\end{array}$ & Singapore, 13-16 November 2018 \\
\hline $\begin{array}{l}\text { Ad Hoc Working Group Meetings on the Guidelines for Maritime Interaction } \\
\text { and Principles for ADMM-Wide Education and Training Exchanges }\end{array}$ & Manila, 19-23 November 2018 \\
\hline ASEAN-United States Maritime Exercise Initial Planning Conference & Singapore, 26 April 2019 \\
\hline $\begin{array}{l}\text { ADMM-Plus Experts' Working Group on Maritime Security and Field } \\
\text { Training Exercise }\end{array}$ & Busan, 29 April - 13 May 2019 \\
\hline ASEAN-United States Maritime Exercise Final Planning Conference & Pattaya, 11-12 July 2019 \\
\hline ASEAN-US Maritime Exercise & $\begin{array}{l}\text { Thailand and Singapore, 1-7 September } \\
2019\end{array}$ \\
\hline $\begin{array}{l}\text { ADMM-Plus Experts' Working Group on Maritime Security Future Leaders' } \\
\text { Programme }\end{array}$ & Seoul and Busan, 2-7 September 2019 \\
\hline
\end{tabular}

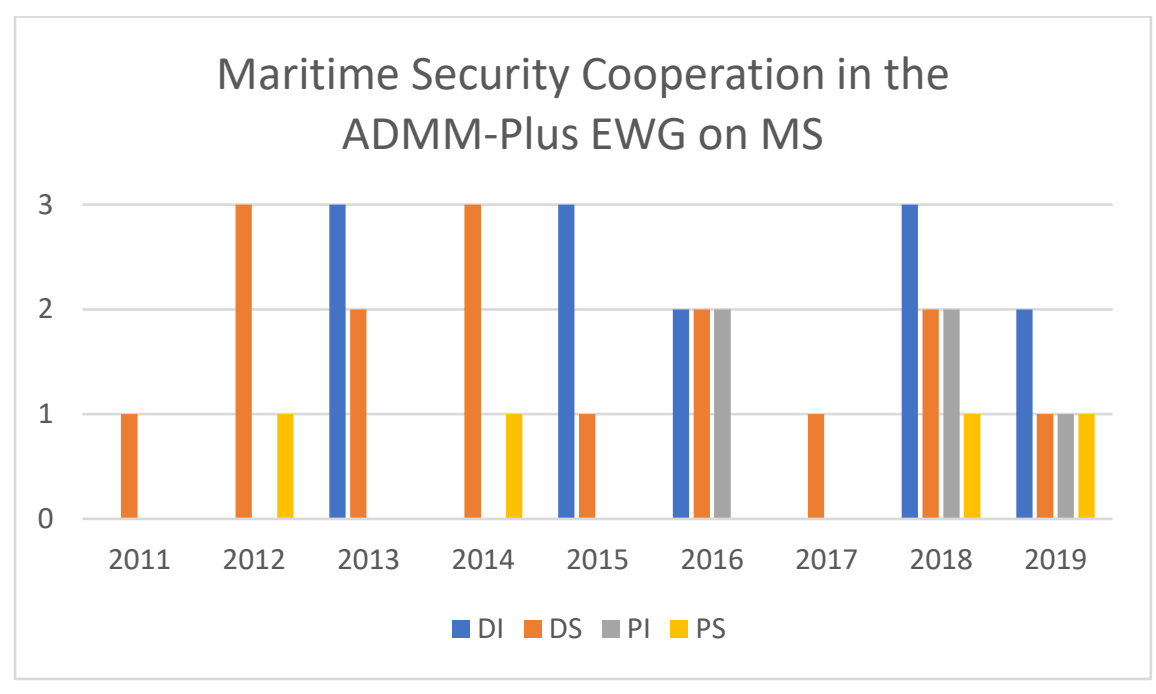

Chart 2. Maritime security cooperation activities in the ADMM and ADMM-Plus, 2011-2019. 
The ADMM and ADMM-Plus have hosted many workshops on maritime security, particularly in maritime security cooperation and capacity building. The ADMM-Plus have also shown to excel in coordinating practical cooperation compared to the ARF. In 2016, for example, the ADMM-Plus managed to organise counterpiracy workshops, maritime security tabletop exercises, the maritime security future leaders programme, the joint ADMM-Plus Maritime and Security and Counter Terrorism Exercise and the Mahi Tangaroa Field Training Exercise. The most notable achievements of the ADMM are the initiation of two large-scale maritime exercises with both China and the US in 2018 and 2019, respectively. The first maritime exercise with China was held in two stages: a table-top exercise held in Singapore in August, followed by a field training exercise in the waters east of Zhanjiang. Singapore, Thailand, Vietnam, Brunei, and the Philippines sent vessels, while Indonesia, Malaysia, Cambodia, and Myanmar observed. The field exercises included search-and-rescue and medical evacuation drills based on the Code of Unplanned Encounters at Sea (CUES). The ASEAN-U.S. Maritime Exercise (AUMX) took place in September 2019. While the U.S. has maintained maritime security cooperation with individual ASEAN members through bilateral initiatives such as the CARAT exercises, the 2019 AUMX represented the U.S.'s first attempt at engaging with all ASEAN member states simultaneously (Parameswaran, 2018).

\section{The ASEAN Maritime Forum (AMF) and Expanded ASEAN Maritime Forum (EAMF)}

The Vientiane Action Programme planned for the eventual creation of an ASEAN maritime forum as a means to promote regional maritime security cooperation, a goal which was further emphasised in the APSC Blueprint. Hitherto, ASEAN lacked a specialised intramural forum for discussing maritime security issues, as maritime problems would often be discussed in conjunction with other sectoral bodies, such as the ASEAN Ministers Meeting on Transnational Crime and the ASEAN Environment Ministers Meeting. In September 2007, Indonesia hosted a workshop on the concept of the AMF, resulting in the Concept Paper on the Establishment of an ASEAN Maritime Forum, which was proposed to the ASEAN Senior Officer Meeting in May 2008. A year later, the Concept Paper was adopted and in 2010, the inaugural AMF was held in Surabaya. It would be the only intramural ASEAN forum where maritime security issues could be discussed comprehensively based on ASEAN principles (Rijal, 2019).

Though the AMF was intended to be an intramural forum for building maritime security cooperation, there was support for its expansion. At the $6^{\text {th }}$ East Asia Summit in 2011, Japan proposed to expand the AMF to include ASEAN Dialogue Partners (Midford, 2015). The idea was endorsed by ASEAN leaders, noting that the expanded dialogue would allow members to 'utilize opportunities and address common challenges on maritime issues'. In October 2012, the inaugural EAMF was held. The forum exchanged views on the relevance of UNCLOS, maritime connectivity and capacity building, infrastructure upgrading, seafarers training, marine environment protection, promotion of eco-tourism and fisheries regime in East Asia, and identifying best practices. As of 2020, there have been ten AMF and eight EAMF meetings. The main topics of discussion are summarised in Table 4 . 
Table 4. Summary of AMF and EAMF meetings. Compiled by author from press releases, open-source news, government statements, and conference reports.

\begin{tabular}{|c|c|}
\hline & Issues discussed \\
\hline $1^{\text {st }}$ AMF in Surabaya, & - $\quad$ Maritime connectivity \\
\hline \multirow[t]{3}{*}{ Indonesia, $28-29$ July 2010} & - Maritime security problems \\
\hline & - Search and rescue \\
\hline & $\begin{array}{l}\text { Future work of the AMF, including updating the AMF concept paper, } \\
\text { identifying topics and plans for future AMF meetings, and exploring } \\
\text { avenues for concrete maritime cooperation (Ministry of Foreign Affairs } \\
\text { of Indonesia, 2010). }\end{array}$ \\
\hline $2^{\text {nd }} \mathrm{AMF}$ in Pattaya, & - Safety and security of sea lanes of communication (SLOC) in Southeast \\
\hline Thailand, $17-19$ August & Asia \\
\hline \multirow[t]{3}{*}{2011} & - Maritime domain awareness \\
\hline & - Regional maritime cooperation in search and rescue \\
\hline & $\begin{array}{l}\text { - Future work of the AMF, including stocktaking of issues and } \\
\text { implementation of SLOC safety, maritime domain awareness, and } \\
\text { maritime cooperation (Permal, 2011). }\end{array}$ \\
\hline $3^{\text {rd }}$ AMF in Manila,3-4 & - Maritime security and cooperation in ASEAN \\
\hline \multirow[t]{3}{*}{ October 2012} & $\begin{array}{l}\text { - Freedom and safety of navigation, and addressing sea piracy in the high } \\
\text { seas }\end{array}$ \\
\hline & $\begin{array}{l}\text { - Protecting marine environment and promoting eco-tourism and fisheries } \\
\text { regime }\end{array}$ \\
\hline & - Future work of the AMF (ASEAN, 2012) \\
\hline $1^{\text {st }}$ EAMF in Manila, 5 & - Relevance of UNCLOS \\
\hline \multirow[t]{6}{*}{ October 2012} & - Maritime connectivity and capacity building \\
\hline & - Infrastructure and equipment upgrading \\
\hline & - Seafarers' training proposal \\
\hline & - Protection of marine environment \\
\hline & - Promotion of eco-tourism and fisheries regime \\
\hline & - Identification of best practices of cooperation (ASEAN, 2012) \\
\hline $4^{\text {th }} \mathrm{AMF}$ in Malaysia, $1-2$ & - Enhancing maritime cooperation \\
\hline October 2013 & $\begin{array}{l}\text { - Fostering sectoral coordination and cooperation within ASEAN, mostly } \\
\text { centred on the need to reduce operational redundancies between the AMF } \\
\text { and ASEAN Sectoral Bodies, and discussions of a possible reporting } \\
\text { mechanism. } \\
\text { - Future work of the AMF (Briefing on the Outcomes of the } 4^{\text {th }} \text { ASEAN } \\
\text { Maritime Forum and } 2^{\text {nd }} \text { Expanded ASEAN Maritime Forum by } \\
\text { Malaysia, 2014) }\end{array}$ \\
\hline $2^{\text {nd }}$ EAMF in Malaysia, 3 & - Promoting maritime cooperation between ASEAN and Dialogue Partners. \\
\hline \multirow[t]{3}{*}{ October 2013} & Endorsed U.S. initiative of civilian ASEAN seafarer training. \\
\hline & - Discussion on freedom of navigation in the EEZ \\
\hline & $\begin{array}{l}\text { - Some discussions on the South China Sea (Briefing on the Outcomes of } \\
\text { the } 4^{\text {th }} \text { ASEAN Maritime Forum and } 2^{\text {nd }} \text { Expanded ASEAN Maritime } \\
\text { Forum by Malaysia, 2014) }\end{array}$ \\
\hline
\end{tabular}


Table 4. Summary of AMF and EAMF meetings. Compiled by author from press releases, open-source news, government statements, and conference reports.

\section{(Continued)}

\begin{tabular}{|c|c|}
\hline & Issues discussed \\
\hline $5^{\text {th }} \mathrm{AMF}$ and $3^{\text {rd }}$ EAMF in & - Evaluation of implementation of initiatives proposed in previous for a \\
\hline Da Nang, Vietnam, $26-28$ & - Future work for the AMF and EAMF \\
\hline August 2014 & $\begin{array}{l}\text { - Experience sharing in marine research, disaster response, maritime } \\
\text { security and connectivity, search and rescue, and prevention and } \\
\text { managements of incidents at sea (Da Nang Today, 2014). }\end{array}$ \\
\hline $6^{\text {th }} \mathrm{AMF}$ and $4^{\text {th }} \mathrm{EAMF}$ in & - Regional regimes on marine resources \\
\hline Manado, Indonesia, 9-10 & - Enhancement of maritime cooperation \\
\hline September 2015 & - Regional maritime security challenges (Badan Keamanan Laut, 2015) \\
\hline $\begin{array}{l}7^{\text {th }} \text { AMF and } 5^{\text {th }} \text { EAMF in } \\
\text { Jakarta, Indonesia, } 6-7\end{array}$ & $\begin{array}{l}\text { - Advancing cooperation in maritime safety, such as in search and rescue } \\
\text { and prevention of incidents at sea }\end{array}$ \\
\hline December 2017 & $\begin{array}{l}\text { - } \quad \text { Countering piracy, IUU fishing, and human trafficking } \\
\text { - } \quad \text { Protection of marine environment: reducing pollution and coastal } \\
\text { management (Setnas ASEAN Indonesia, 2017) }\end{array}$ \\
\hline $8^{\text {th }} \mathrm{AMF}$ and $6^{\text {th }} \mathrm{EAMF}$ in & - Maritime security and safety \\
\hline Manila, 6-7 December 2018 & $\begin{array}{l}\text { - } \quad \text { Maritime environment protection } \\
\text { - Future work of the AMF and EAMF (Ministry of Foreign Affairs of } \\
\text { Japan, 2018) }\end{array}$ \\
\hline $9^{\text {th }} \mathrm{AMF}$ and $7^{\text {th }} \mathrm{EAMF}$ in & - Maritime security and safety \\
\hline Da Nang, Vietnam, 5-6 & - Search and rescue and anti-piracy \\
\hline December 2019 & $\begin{array}{l}\text { - } \quad \text { Combating illegal fishing } \\
\text { - Promoting environmental protection and dealing with plastic waste (Da } \\
\text { Nang Today, 2019) }\end{array}$ \\
\hline $10^{\text {th }} \mathrm{AMF}$ and $8^{\text {th }}$ EAMF in & - Addressed 'emerging challenges' at sea \\
\hline Hanoi, Vietnam, 12-13 & - Need to take steps to 'enhance information exchange and coordination' \\
\hline December 2020 & $\begin{array}{l}\text { - 'Promoting links between strategies and initiatives on maritime } \\
\text { cooperation' } \\
\text { - Support for the ASEAN Outlook on the Indo-Pacific (Viet Nam News, } \\
\text { 2020). }\end{array}$ \\
\hline
\end{tabular}

\section{DISCUSSION}

\section{Comparing the ARF, ADMM, and AMF: a thematic analysis}

The ARF ISM on MS and AMF (along with the EAMF) tend to be heavily processoriented, resulting in a format which privileges dialogue and agenda-setting over practical acts of cooperation. Granted, a degree of dialogue is necessary to facilitate smoother cooperation in the future and to allow states to progress at a comfortable pace, especially in a setting where member states have divergent threat perceptions and preferred approaches to maritime security cooperation. In this respect, these institutions fulfil their intended purpose, as it provides a meeting point where these differences may be discussed, and common ground be found. However, as Yuzawa (2006) rightly observed, uniting the divergent and often opposing perceptions of ARF members (particularly on preventive diplomacy) is often labour-intensive. The intergovernmental nature of the organisation also adds to the high possibility of discussions 
becoming stalled, either intentionally or unintentionally. Critics of these processes have pointed out the relatively lacklustre stream of practical output as evidence of either failure or a lack of value of these institutions. An oft-repeated criticism levied on the ARF is that it is a 'talk shop' with limited means of delivering results (see, for example, Garofano, 1999).

Proponents of the ARF process point out that the Forum was never intended to act as a sort of hub where practical maritime security cooperation was the main goal. As Katsumata (2006) writes, the ARF should be considered as a 'norm brewery' in the Asia Pacific, as it allows member states to develop and practice relevant norms in security cooperation. In this sense, the constant stream of dialogue-based outcomes of the ISM on MS ought to be viewed as a positive sign of the ARF's relevance. As the data shows, though the ARF has indeed been engaged in more sustained dialogue, this does not necessarily translate to more sustained practical cooperation in maritime security. This is consistent with the conclusions of previous research on the ARF (Haacke, 2009; Mak, 2010). In fact, the more intricate practical cooperation initiatives, such as regional information-sharing and naval and field exercises, are often practiced outside of the ARF.

The ADMM and ADMM-Plus demonstrate a refinement of promoting and institutionalising maritime security cooperation beyond the bilateralism that characterised ASEAN security (usually military-to-military) cooperation in the 1970s to 1990s. Having learned from the pitfalls of the ARF, the ADMM-Plus actively sought to limit its membership, reducing the probability of friction due to divergent threat perceptions and interests. As Dialogue partner members are required to have 'significant interactions and relations with ASEAN defence establishments' and must show commitment to be 'able to work with the ADMM to build capacity so as to enhance regional security in substantive manner' with ADMM members prior to their acceptance into the ADMM-Plus, the ADMM-Plus can dedicate more time to addressing practical solutions instead of building trust through exchanges and dialogue (Chalermpalanupap, 2011). In a way, the previous 'informal luncheons', which then evolved into the ARF Defence Officials Dialogue, provided the foundation the ADMM-Plus needed to expedite the implementation of practical cooperation (Tan, 2012, p. 242). In other words, though still being process-oriented, the ADMM-Plus is also more outcome-oriented compared to the ARF and AMF, as the formal working group setting allows the ADMM-Plus members to quickly formulate plans of cooperation in multiple areas.

While the ADMM and ADMM-Plus have indeed contributed much to advancing practical security cooperation, they have also been criticised of being exclusively focused on non-traditional maritime security issues. The primary scope of the EWG on MS continues to be issues of maritime piracy, humanitarian assistance and disaster relief, and counterterrorism. The non-traditional focus prevents deeper discussion and preparation on other, often pressing traditional maritime security issues which would require a higher degree of operational sophistication in the maritime domain, such as the South China Sea dispute (Mukherjee, 2013; Tan, 2017; Tang, 2016). In addition, as the ADMM-Plus programmes continue to increase in complexity and intensity, Tan (2020, p. 37) fears members may suffer from 'participant fatigue'. In the long run, there are concerns that ADMM-Plus members may grow disillusioned 
of the capability of the ADMM-Plus to address 'high politics' issues related to the maritime domain.

The AMF occupies an awkward position within ASEAN's intricate network of maritime security cooperation, which impacts its performance. On one side, the ARF continues to be the premier forum for region-wide dialogue on maritime security due to its expansive network. On the other side, the ADMM and ADMM-Plus already provide platforms for practical maritime security cooperation on top of existing bilateral and 'mini-lateral' maritime security cooperation. The presence of the AMF and its expanded version seems to be overshadowed by these existing fora. As Muhibat (2017) observed, this might indicate members questioning the value of the AMF and EAMF as venues for maritime security cooperation, especially as other venues provide similar benefits. In addition, the AMF also adds to the many annual events that ASEAN members are already required to attend, stretching diplomatic resources thin.

Despite holding routine discussions, the output of the AMF and EAMF remains rather limited. One form of cooperation to emerge from the EAMF was the first Expanded ASEAN Seafarer Training Counter-Piracy Workshop, held in Manila on 23-25 September 2013. The workshop was joined by all 18 EAS members and resulted in numerous recommendations for increasing support and training for seafarers (EAMF, 2013). As a dialogue-first and processoriented forum, the AMF and EAMF can only pass on these recommendations to the relevant ASEAN sectoral bodies. Implementation, then, is highly dependent on the sectoral bodies and member states. In other words, the AMF and EAMF may still need to carve out their own niche among the many regional platforms for cooperation within ASEAN.

\section{Does the driver matter?}

Still along the lines of institutional design, there is an obvious difference of the main drivers involved in the three fora. In the ARF and AMF, the primary drivers are foreign ministers, whereas in the ADMM, the primary participants are defence officials. Tan (2016, p. 74) points out that defence officials, with their 'mission-mindedness and the military assets and resources at their disposal', often perform better compared to foreign ministers. The data corroborates this observation; the practical output of the ADMM-Plus eclipses the combined output of ARF and AMF.

Could this be attributed to the functional expertise of the drivers? There are at least two reasons to accept the hypothesis. First, ASEAN militaries have had a long history of functional interaction. From the 1970s, security cooperation was usually centred on bilateral annual and intermittent military-to-military exercises. These exercises were deliberately kept separate from the formal multilateral channels, as foreign ministers were cautious of presenting ASEAN as a military bloc during the Cold War (Chalermpalanupap, 2011, p. 19). These military-tomilitary interactions were then integrated within the ASEAN framework in the 2000s, as ASEAN defence officials were provided with specific sub-regional umbrellas to conduct cooperation. It stands to reason that this prolonged period of cooperation, free from the constraints of regional diplomacy, has provided ASEAN militaries with the modalities to 
formulate security cooperation at a pace comfortable to all. Second, foreign ministers tend to be overtly bound by the formalities attached with regional diplomacy and national interests, whereas defence officials tend to take a pragmatic approach to security cooperation, albeit still within the constraints of regional and national preferences. These different approaches may be observed within the ARF and ADMM. Advancements of maritime security cooperation in the ARF tend to be hindered by an aversion to overt military-to-military exercises, which were deemed 'unfeasible' by the foreign ministers of the ARF (Tan, 2016, p. 74). This may stem from the ARF's emphasis on respecting sovereignty and a lack of interoperability among ARF militaries (Haacke, 2009, p. 445). In stark contrast, the ADMM-Plus, defence officials were quick to discuss and plan Exercise Mahi Tangaroa in 2016, requiring only eleven months from discussion to implementation.

\section{Practical cooperation guided by preferences?}

Despite these trends towards deeper formalization of maritime security cooperation at the multilateral level, most of the practical maritime security cooperation in Southeast Asia occurs outside the purview of ASEAN-related institutions. The data in the previous section is limited to intra-ASEAN practical maritime security cooperation; however, ASEAN members have long cooperated with extra-regional powers in maritime security. The United States, for example, continues to provide capacity building, training, and funding through its Southeast Asia Maritime Security Initiative (which was renamed the 'Indo-Pacific Maritime Security Initiative' during the Trump administration). Since 1995, the United States has been carrying out the Cooperation Afloat Readiness and Training and Southeast Asia Cooperation against Terrorism (SEACAT) exercises, which provide training and capacity building in counterpiracy and counterterrorism. Likewise, Japan has made significant contributions to Southeast Asian states in the form of technical assistance, capacity building, and funding, mostly under the ReCAAP framework (Llewelyn, 2017; Son, 2013).

ASEAN members also sometimes resort to intra-regional cooperative options outside the institutional boundaries of ASEAN. One notable example is the trilateral patrols in the Sulu Sea (modelled after the Malacca Strait Patrols), launched by Indonesia, Malaysia, and the Philippines in 2017 in response to rising levels of transnational crime. The initial idea for the patrols was proposed in as early as May 2016 and formal operations began in June 2017. Though not having to go through the complex bureaucracy of ASEAN, the delay in the implementation was caused by sovereignty concerns and logistical constraints between the three parties (Storey, 2018). These examples may indicate that a 'mini-lateral' approach to maritime security cooperation may be preferable to ASEAN members, particularly if ASEAN members were to increase cooperation to include more contentious regional issues (Heydarian, 2017). 


\section{CONCLUSION}

This paper sought to expand on Haacke's initial observation that security cooperation in ASEAN was more dialogue-oriented compared to being practical, although there is a slight positive trend towards more practical forms of cooperation. The review of the activities and outcomes of the ARF ISM on MS, the ADMM and ADMM-Plus EWG on Maritime Security, and the AMF and EAMF generally supports Haacke's observation. Among ASEAN institutions, maritime security cooperation is largely dialogue-based in the form of routine dialogues and periodic thematic workshops designed to increase the capacity of relevant state maritime security agencies. Practical cooperation, however, remains few and far between, particularly in the ARF and AMF, due to the respective organisational design and purposes. The notable exception is the ADMM-Plus, which has been shown to be capable of organising sustained feats of practical maritime security cooperation among ASEAN members and nonASEAN members.

From 2003 onwards, ASEAN decided to focus on maritime security as a problem to be handled collectively, which necessitated a more formal, institutionalised approach to solving the maritime security problems. The institutionalisation of maritime security is reflected in the further specialisation of multilateral fora within the ASEAN framework, namely the ARF, ADMM, and AMF. These three institutions have their respective strengths and weaknesses in promoting maritime security cooperation, many of which stem from their institutional purposes and design. At the core of these weaknesses are divergent perceptions of maritime security. In these regional institutions, which are well-designed to promote confidence-building and dialogue, opposing views often require a lot of time to reach an operational level of accommodation before action is taken. As a result, the outcomes of these institutions are mostly dialogue and exchanges, with more concrete, practical forms of cooperation being few and far between, and often conducted outside the confines of regional institutions. As regional institutions remain hamstrung in promoting practical maritime security cooperation, further research might be interested in investigating the 'mini-lateral' turn in maritime security cooperation, particularly its proposed benefits and drawbacks compared to multilateralism. Additionally, future research may choose to investigate the divergent perceptions between the foreign policy elite with the defence officials, which have been hypothesized to affect institutional preferences.

\section{ABOUT THE AUTHORS}

I Gusti Bagus Dharma Agastia is an Assistant Professor at the International Relations Study Programme at President University. 


\section{REFERENCES}

Acharya, A. (2009a). Arguing about ASEAN: What do we disagree about? Cambridge Review of International Affairs, 22(3), 493-499. https://doi.org/10.1080/09557570903138444

Acharya, A. (2009b). Constructing a Security Community in Southeast Asia (2nd ed.). Routledge.

ARF. (2006). ARF Maritime Shore Exercise: a concept paper. http://aseanregionalforum.asean.org/wp-content/uploads/2019/05/annex7-ARF-SOMKarambunai-Malaysia-2006.pdf

ARF. (2007). Co-Chairs'Summary Report of the ARF Roundtable Discussion on Stocktaking Maritime Security Issues Bali, 24-25 August 2007. http://aseanregionalforum.asean.org/wp-content/uploads/2019/03/Document-2Report-of-ARF-Roundtable-Discussion-on-Stocktaking-Maritime-Security-Issues.pdf

ARF. (2018). ASEAN Regional Forum Work Plan For Maritime Security 2018-2020. http://aseanregionalforum.asean.org/wp-content/uploads/2019/01/ARF-MaritimeSecurity-Work-Plan-2018-2020.pdf

ARF. (2019). ARF Workshop and Table Top Exercise on Crimes Related to Fisheries. http://aseanregionalforum.asean.org/wp-content/uploads/2019/01/ANNEX-25-10thISM-on-MS.pdf

ASEAN. (2009). ASEAN Political Security Community Blueprint 2015. ASEAN Secretariat.

ASEAN. (2012, October 9). Chairman's Statement, 3rd ASEAN Maritime Forum. https://asean.org/chairman-s-statement-3rd-asean-maritimeforum/https://asean.org/chairman-s-statement-3rd-asean-maritime-forum/

Ba, A. D. (2017). ASEAN and the Changing Regional Order: The ARF, ADMM, and ADMMPlus. In A. Baviera \& L. Maramis (Eds.), Building ASEAN Community: PoliticalSecurity and Socio-cultural Reflections (pp. 146-157). Economic Research Institute for ASEAN and East Asia.

Badan Keamanan Laut. (2015, September 11). Bakamla Menghadiri 6th Asean Maritime Forum Dan 4th Expanded Asean Maritime Forum. https://www.bakamla.go.id/home/artikel_lengkap/1271/f82cb5679fc339f62a9853f439 $\underline{\mathrm{f} 14 \mathrm{ff} 2}$

Bhattacharyya, A. (2010). Understanding Security in Regionalism Framework: ASEAN Maritime Security in Perspective. Maritime Affairs, 6(2), 72-89. https://doi.org/10.1080/09733159.2010.559786

Bradford, J. (2005). The Growing Prospects for Maritime Security Cooperation in Southeast Asia. Naval War College Review, 58(3), 63-86. 
Briefing on the outcomes of the 4th ASEAN Maritime Forum and 2nd Expanded ASEAN Maritime Forum by Malaysia. (2014). http://aseanregionalforum.asean.org/wpcontent/uploads/2019/03/Annex-7-Briefing-on-the-Outcomes-of-the-4th-AMF-and2nd-EAMF-6th-ism-on-ms.pdf

Chalermpalanupap, T. (2011). Carving Out a Crucial Role for ASEAN Defence Establishments in the Evolving Regional Architecture. In B. Singh \& S. S. Tan (Eds.), From "Boots to Brogues": The rise of defence diplomacy in Southeast Asia (pp. 18-27). S. Rajaratnam School of International Studies.

Da Nang Today. (2014, August 26). ASEAN maritime forums being held in the city. https://baodanang.vn/english/politics/201408/asean-maritime-forums-being-held-inthe-city-2354944/

Da Nang Today. (2019, December 5). The city hosts 9th ASEAN Maritime Forum. https://www.baodanang.vn/english/politics/201912/the-city-hosts-9th-asean-maritimeforum-3266153/

Damayanti, A. (2018). Regional Maritime Cooperation in Maintaining Maritime Security and Stability: A Test Case for ASEAN Unity and Centrality. Journal of ASEAN Studies, 5(2), 119. https://doi.org/10.21512/jas.v5i2.1888

EAMF. (2013). Expanded ASEAN Seafarer Training - Counter Piracy (EAST-CP) Co-

Chairs' Report. http://aseanregionalforum.asean.org/wpcontent/uploads/2019/03/Annex-17-Co-Chairs-Report-of-EAST-CP-Workshop-andSeminar-6th-ism-on-ms.pdf

Eaton, S., \& Stubbs, R. (2006). Is ASEAN powerful? Neo-realist versus constructivist approaches to power in Southeast Asia. Pacific Review, 19(2), 135-155. https://doi.org/10.1080/09512740500473148

Febrica, S. (2015). Why Cooperate? Indonesia and Anti-Maritime Terrorism Cooperation. Asian Politics \& Policy, 7(1), 105-130. https://doi.org/10.1111/aspp.12162

Garofano, J. (1999). Flexibility or Irrelevance: Ways Forward for the ARF. Contemporary Southeast Asia, 21(1), 74-94.

Haacke, J. (2009). The ASEAN Regional Forum: From dialogue to practical security cooperation? Cambridge Review of International Affairs, 22(3), 427-449.

Heydarian, R. J. (2017, November 7). Time For ASEAN Minilateralism. RSIS Commentaries. https://hink-asia.org/bitstream/handle/11540/7852/CO17210.pdf

House Armed Services Committee. (2004). Testimony of Admiral Thomas B. Fargo, United States Navy, Commander, U.S. Pacific Command Before the House Armed Services Committee Regarding U.S. Pacific Command Posture. https://web.archive.org/web/20051217225845/https://www.pacom.mil/speeches/sst20 04/040331housearmedsvcscomm.shtml 
Jones, D. M., \& Smith, M. L. R. (2007). Making Process, Not Progress: ASEAN and the Evolving East Asian Regional Order. International Security, 32(1), 148-184. https://doi.org/10.1162/isec.2007.32.1.148

Jones, L. (2010). Asean's unchanged melody? The theory and practice of "non-interference" in Southeast Asia. Pacific Review, 23(4), 479-502. https://doi.org/10.1080/09512748.2010.495996

Katsumata, H. (2006). Establishment of the ASEAN Regional Forum: Constructing a "talking shop" or a "norm brewery"? Pacific Review, 19(2), 181-198. https://doi.org/10.1080/09512740500473197

Llewelyn, J. D. (2017). Preventive Diplomacy and the Role of Civil Maritime Security Cooperation in Southeast Asia. Strategic Analysis, 41(1), 49-60. https://doi.org/10.1080/09700161.2016.1249178

Mak, J. N. (2010). Maritime security and the ARF. In J. Haacke \& N. M. Morada (Eds.), Cooperative Security in the Asia-Pacific: The ASEAN Regional Forum (pp. 172-198). Routledge.

Midford, P. (2015). Japan's Approach to Maritime Security in the South China Sea. Asian Survey, 55(3), 525-547. https://doi.org/10.1525/as.2015.55.3.525

MINDEF. (2007). SINGAPORE HOSTS FIRST EVER ASEAN REGIONAL FORUM MARITIME SECURITY SHORE EXERCISE. https://www.nas.gov.sg/archivesonline/data/pdfdoc/20070123980.htm

Ministry of Foreign Affairs of Indonesia. (2010, July 29). 1st Meeting of ASEAN Maritime Forum. $\quad$ https://ex.kemlu.go.id/en/berita/siaran-pers/Pages/1st-Meeting-Of-AseanMaritime-Forum-AMF.aspx

Ministry of Foreign Affairs of Japan. (2018, December 18). The 6th Expanded ASEAN Maritime Forum. https://www.mofa.go.jp/fp/msp/page25e_000277.html

Muhibat, S. F. (2017). AMF and EAMF: an uncertain future? RSIS Commentaries. http://hdl.handle.net/11540/11046

Mukherjee, A. (2013, August 22). ADMM-Plus: Talk Shop or Key to Asia-Pacific Security? The Diplomat. https://thediplomat.com/2013/08/admm-plus-talk-shop-or-key-to-asiapacific-security/

Nasu, H., McLaughlin, R., Rothwell, D. R., \& Tan, S. S. (2019). The Legal Authority of ASEAN as a Security Institution. Cambridge University Press.

Parameswaran, P. (2018, October 22). Why the First China-ASEAN Maritime Exercise Matters. The Diplomat. https://thediplomat.com/2018/10/why-the-first-china-asean-maritimeexercise-matters/ 
Permal, S. (2011). The 2nd ASEAN Maritime Forum, 17-19 August 2011, Pattaya, Thailand. Australian Journal of Maritime \& Ocean Affairs, 3(4), 140-143. https://doi.org/10.1080/18366503.2011.10815693

Rijal, N. K. (2019). Kepentingan Nasional Indonesia dalam Inisiasi ASEAN Maritime Forum (AMF). Indonesian Perspective, 3(2), 159-17.https://doi.org/10.14710/ip.v3i2.22350

Rosenberg, D., \& Chung, C. (2008). Maritime Security in the South China Sea: Coordinating Coastal and User State Priorities. Ocean Development \& International Law, 39(1), 5168. https://doi.org/10.1080/00908320701641602

Setnas ASEAN Indonesia. (2017, December 5). Indonesia Pimpin Penguatan Kerja Sama Maritim di Kawasan. http://setnas-asean.id/siaran-pers/read/indonesia-pimpinpenguatan-kerja-sama-maritim-di-kawasan

Son, N. H. (2013). ASEAN-Japan Strategic Partnership in Southeast Asia: Maritime Security and Cooperation. In R. Sukma \& Y. Soeya (Eds.), Beyond 2015: ASEAN-Japan Strategic Partnership for Democracy (pp. 214-227). Japan Center for International Exchange.

Storey, I. (2009). Maritime Security in Southeast Asia: Two Cheers for Regional Cooperation. In D. Singh (Ed.), Southeast Asian Affairs (pp. 36-58). ISEAS.

Storey, I. (2018, August 27). Trilateral Security Cooperation in the Sulu-Celebes Seas: a work in progress. ISEAS Perspective. https://www.iseas.edu.sg/images/pdf/ISEAS_Perspective_2018_48@50.pdf

Stubbs, R. (2019). ASEAN sceptics versus ASEAN proponents: evaluating regional institutions. The Pacific Review, 32(6), 923-950. https://doi.org/10.1080/09512748.2019.1611627

Tan, S. S. (2012). 'Talking Their Walk'? The Evolution of Defense Regionalism in Southeast Asia. Asian Security, 8(3), 232-250. https://doi.org/10.1080/14799855.2012.723919

Tan, S. S. (2016). The ADMM-plus: Regionalism that works? Asia Policy, 22(1), 70-75. https://doi.org/10.1353/asp.2016.0024

Tan, S. S. (2017). A Tale of Two Institutions: The ARF, ADMM-Plus and Security Regionalism in the Asia Pacific. Contemporary Southeast Asia, 39(2), 259-264.

Tan, S. S. (2020). Is ASEAN Finally Getting Multilateralism Right? From ARF to ADMM+. Asian Studies Review, 44(1), 28-43. https://doi.org/10.1080/10357823.2019.1691502

Tang, S. M. (2016). ASEAN and the ADMM-plus: Balancing between strategic imperatives and functionality. Asia Policy, 22(1), 76-82. https://doi.org/10.1353/asp.2016.0029 
Viet Nam News. (2020, December 17). ASEAN maritime cooperation reaps fruit amidst COVID-19. Vietnam News. https://vietnamnews.vn/politics-laws/830097/aseanmaritime-cooperation-reaps-fruit-amidst-covid-19.html

Yates, R. (2017). ASEAN as the 'regional conductor': understanding ASEAN's role in AsiaPacific order. The Pacific Review, 30(4), 443-461. https://doi.org/10.1080/09512748.2016.1264458

Yuzawa, T. (2006). The evolution of preventive diplomacy in the ASEAN regional forum: Problems and prospects. Asian Survey, 46(5), 785-804. https://doi.org/10.1525/as.2006.46.5.785 